\title{
On the Experimental Study of Tuyere Model Ablation and Its Heat Transfer Analysis*
}

\author{
By Syogo MATSUNAGA, ${ }^{* *}$ Hiroshi YAMAOKA, ${ }^{* *}$ Morio KAWASAKI ${ }^{* *}$ \\ and Koichi HARADA***
}

\section{Synopsis}

Through the examination of broken blast furnace tuyeres, it was found that $43 \%$ of the failure occurred at upper wall, $45 \%$ at lower wall, $12 \%$ at side wall and $73 \%$ at outer wall of tuyere. The ablated failure occurred at the upper and lower parts of outer and edge walls of tuyere, and the failure of this type exceeded almost $80 \%$ of the total failures.

The experimental studies on the ablation failure of blast furnace tuyere were made by using the model tuyeres made of copper, phospher bronze and brass having the wall thickness of $15 \mathrm{~mm}$. In this study, the velocity of cooling water was kept at 3 to $4 \mathrm{~m} / \mathrm{sec}$ on the inner surface of model tuyere, and molten iron was poured onto the side wall of model tuyere.

On the basis of the experimental ablation data of model tuyeres, the heat transfer simulation model of ablation was established, in which the heat transfer coefficients were determined by using an electronic computer.

In the heat transfer simulation model, the velocity of cooling water should be over $13 \mathrm{~m} / \mathrm{sec}$ if the burn-out data published by McAdams is taken into consideration.

Further, an investigation was also made on the effects of the thickness of tuyere wall and its thermal conductivity on the ablation speed of tuyere.

\section{Introduction}

The failure of the blast furnace tuyeres sometimes hampers the normal blast furnace operation and the productivity of iron will be enormously decreased in case of large blast furnaces.

In this study, the following three items have been examined:

1) Investigation of the failure types of blast furnaces

2) Experimental studies on the ablation phenomena of model tuyere

3) Determination of the ablation characteristics of model tuyere by the heat transfer simulation model

Influences of the material and the thickness of tuyere wall on the ablation characteristics based on the heat transfer model were also studied.

\section{Characteristics of the Failure of Our Blast Furnace Tuyeres}

1. Configuration of Broken Tuyeres

Table 1 shows the configuration of broken tuyeres of our blast furnaces for last two years and the configurations of broken tuyeres can be classified by their positions. The configurations of broken tuyeres are different at every blast furnaces, though it should be realized that more than $80 \%$ of the failures are by the ablation.

\section{Damaged Section of Tuyere}

The damaged sections of tuyeres are summarized in Table 2. Among the failures occurred in the peripheral direction, $43 \%$ of them occurred at the upper zone, $45 \%$ at the lower zone and $12 \%$ at the side zone; and among the failures occurred in the radial direction, $73 \%$ of them occurred at the outer wall of the tuyeres.

Table 3 shows the enormously ablated failure occurred at the tuyere. From these tables, it is found that the ablated failure mainly occurred at the upper and lower parts of the outer wall and the edge wall of tuyeres, and the number of failures of this type exceeded almost $80 \%$ of the total failures.

\section{Experiment on the Ablation Failure of Model Tuyere}

\section{Experimental Apparatus and Its Operations}

Figure 1 shows a schematic view of the experimental apparatus. This apparatus consists of two basins, Nos. 1 and 2, and a sliding support of the model tuyeres. Iron of about $20 \mathrm{~kg}$ melted by a high-frequency induction furnace was poured into the basin No. 1. The molten iron was poured into the basin No. 2 by opening the stopper of the basin No. 1, and then flowed out to the side wall of the model tuyere through the nozzle (diameter $10 \mathrm{~mm}$ ) with a constant velocity. After exposing to the molten iron for a certain period of time, the model tuyere was pulled out. The temperature of the molten iron in the basin was $1400^{\circ} \mathrm{C}$ and the wall thickness of the model tuyere was $15 \mathrm{~mm}$.

The weight of the molten iron poured was about

Table 1. Classification of blast furnace tuyere failures, and number of failed tuyeres in each examined period

\begin{tabular}{|c|c|c|c|c|c|c|c|c|c|}
\hline No. of blast furnace & 1 & 2 & 3 & 4 & 5 & 6 & 7 & 8 & \multirow{2}{*}{$\begin{array}{c}\text { Mean value } \\
(\%)\end{array}$} \\
\hline $\begin{array}{ll}\text { Period } & \begin{array}{l}\text { from } \\
\text { to }\end{array}\end{array}$ & $\begin{array}{l}1970.4 \\
1972.3\end{array}$ & $\begin{array}{l}1970.7 \\
1972.6\end{array}$ & $\begin{array}{l}1970.1 \\
1971.12\end{array}$ & $\begin{array}{l}1970.4 \\
1972.3\end{array}$ & $\begin{array}{l}1970.4 \\
1972.2\end{array}$ & $\begin{array}{l}1970.9 \\
1972.7\end{array}$ & $\begin{array}{l}1970.4 \\
1972.3\end{array}$ & $\begin{array}{l}1971.1 \\
1972.3\end{array}$ & \\
\hline Ablation failure & 85 & 39 & 92 & 77 & 59 & 100 & 97 & 100 & 80 \\
\hline Worn out failure & 15 & 53 & 5 & 16 & 31 & 0 & 3 & 0 & 15 \\
\hline Failure by crack & 0 & 8 & 3 & 7 & 10 & 0 & 0 & 0 & 5 \\
\hline
\end{tabular}

* Originally published in Tetsu-to-Hagané, 60 (1974), 177, in Japanese. English version received October 3, 1975.

** Central Research Laboratories, Sumitomo Metal Industries Ltd., Nishinagasu-Hondori, Amagasaki 660.

*** Kashima Steel Works, Sumitomo Metal Industries Ltd., Kashimacho, Kashima-gun 314. 
Table 2. The failure positions of blast furnace tuyeres

\begin{tabular}{|c|c|c|c|c|c|c|c|c|c|c|c|}
\hline No. of bla & urnace & 1 & 2 & 3 & 4 & 5 & 6 & 7 & 8 & Me: & an value $(\%)$ \\
\hline \multirow{3}{*}{ Peripheral direction $* 1$} & Upper zone & 21 & 50 & 11 & 49 & 59 & 73 & 42 & 100 & 437 & \multirow{3}{*}{$43+45=88 \%$} \\
\hline & Side zone & 19 & 33 & 13 & 5 & 6 & 13 & 21 & 0 & 12 & \\
\hline & Lower zone & 60 & 17 & 76 & 46 & 35 & 14 & 37 & 0 & 45 & \\
\hline \multirow{3}{*}{ Radial direction $* 2$} & Outer surface ${ }^{* 3}$ & 70 & 44 & 83 & 85 & 67 & 46 & 42 & 100 & 737 & \multirow{3}{*}{$73+17=90 \%$} \\
\hline & End surface & 17 & 44 & 14 & 8 & 14 & 46 & 38 & 0 & $17^{\rfloor}$ & \\
\hline & Inner surface*4 & 13 & 12 & 3 & 7 & 19 & 8 & 20 & 0 & 10 & \\
\hline
\end{tabular}
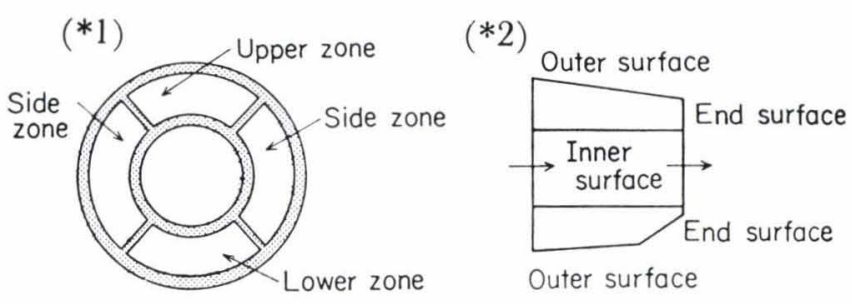

Outer surface

Table 3. Upper and lower parts failure, outer and end surface failure, and failure by ablation of the blast furnace tuyere

\begin{tabular}{c|ccccc}
\hline No. of blast furnace & 6 & 8 & 7 & 3 & 1 \\
\hline Failure by ablation (\%) & 100 & 100 & 97 & 92 & 85 \\
\hline $\begin{array}{l}\text { Upper and lower parts } \\
\text { failure (\%) }\end{array}$ & 97 & 100 & 79 & 87 & 81 \\
$\begin{array}{l}\text { Outer and end surface } \\
\text { failure (\%) }\end{array}$ & 92 & 100 & 80 & 97 & 87 \\
\hline
\end{tabular}
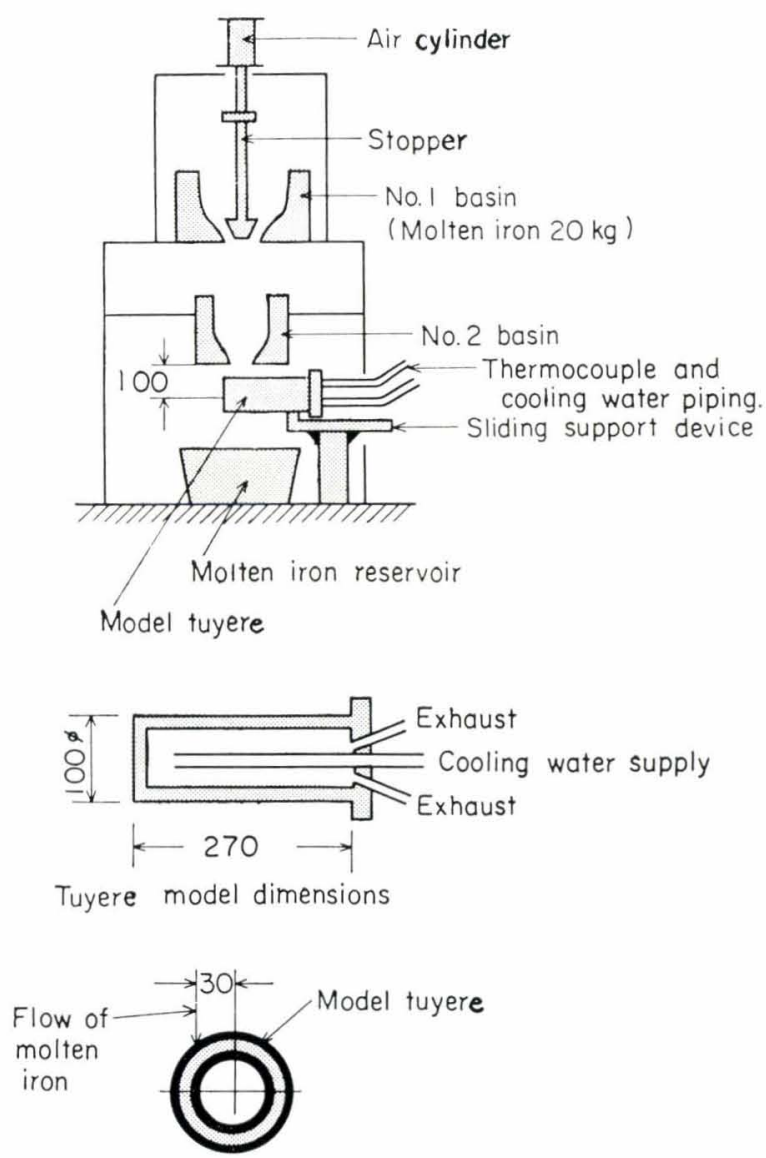

Fig. 1. Schematic expression of ablation test device for model tuyere
*1 Peripheral direction

$* 2$ Radial direction

*3 Outer surface includes outer edge of end surface

*4 Inner surface includes inner edge of end surface

$10 \mathrm{~kg}$. The flow rate of cooling water was about $13.6 \mathrm{l} / \mathrm{min}$. The velocity of water along the inner surface of the model tuyere was kept at about 3 to $4 \mathrm{~m} / \mathrm{sec}$. The period of an experiment was about $10 \mathrm{sec}$.

\section{Experimental Results}

The experimental results on the ablated failure obtained by using the model tuyeres are shown in Table 4. Figure 2 shows the results together with the results of the heat transfer simulation model. In this figure the thermal diffusivity is plotted as abscissa and the ablation time which is the ablating period in second as ordinate.

As shown in this figure and Table 4, the model tuyeres made of pure copper were partially ablated by molten iron, but the ablation area was small. On the other hand, the tuyeres made of copper alloys were ablated in a shorter period and the ablated area was large. It was also observed that the model tuyeres made of pure copper without water cooling were ablated in $5 \mathrm{sec}$ but the water cooled model tuyeres could withstand for the period of more than $7 \mathrm{sec}$ as shown in Fig. 2.

\section{Heat Transfer Simulation Model of the Tuyere}

In the heat transfer simulation model, it is difficult to evaluate the effect of the diameter (about $10 \mathrm{~mm}$ ) of the poured molten iron flow.

In the current work, the one-dimentional heat transfer simulation model has therefore been used instead of the three-dimentional model.

\section{Calculation of the Quantity of Heat Transferred before the Initiation of Ablation}

Figure 3 shows the one-dimentional heat transfer simulation model.

If the temperature of the point $\mathrm{MX}$ on the surface of tuyere rises from $T(\mathrm{MX})^{\circ} \mathrm{C}$ to $T D(\mathrm{MX})^{\circ} \mathrm{C}$ for the period of $D T$, the quantity of heat added during the period of $D T$ can be expressed by the following equation.

$$
Q_{0}=C \cdot \rho \cdot V(\mathrm{MX}) \cdot[T D(\mathrm{MX})-T(\mathrm{MX})]
$$

The quantity of heat conducted from the mesh point $\mathrm{MX}$ to $\mathrm{MX}_{1}$ is expressed as follows. 
Table 4. The experimental results of model tuyere ablation by molten iron blowing

\begin{tabular}{|c|c|c|c|c|}
\hline Material of tuyere model & Cooling water & $\begin{array}{l}\text { Molten iron blowing } \\
\text { time (sec) }\end{array}$ & $\begin{array}{l}\text { Ablation area } \\
\qquad\left(\mathrm{mm}^{2}\right)\end{array}$ & $\begin{array}{l}\text { Temperature of } \\
\text { molten iron }\left({ }^{\circ} \mathrm{C}\right)\end{array}$ \\
\hline $\mathrm{Cu}$ & No & 5.0 & $30 \times 50$ & 1320 \\
\hline \multirow{4}{*}{$\mathrm{Cu}$} & Yes & 4.0 & No & 1340 \\
\hline & Yes & 6.0 & No & 1330 \\
\hline & Yes & 7.2 & $30 \times 35$ & 1300 \\
\hline & Yes & 7.6 & $30 \times 35$ & 1380 \\
\hline PBC (Sn 10\%) & Yes & 4.0 & $50 \times 60$ & 1370 \\
\hline BS (Zn 25\%) & Yes & 3.0 & $50 \times 60$ & 1380 \\
\hline $\mathrm{Cu}-\mathrm{Cr}(\mathrm{Cr} 0.5 \%)$ & Yes & 4.0 & $20 \times 30$ & 1270 \\
\hline $\mathrm{Cu}-\mathrm{Cr}-\mathrm{Zr}(\mathrm{Cr}, \mathrm{Zr} \quad 0.5 \%)$ & Yes & 4.0 & $40 \times 60$ & 1230 \\
\hline
\end{tabular}

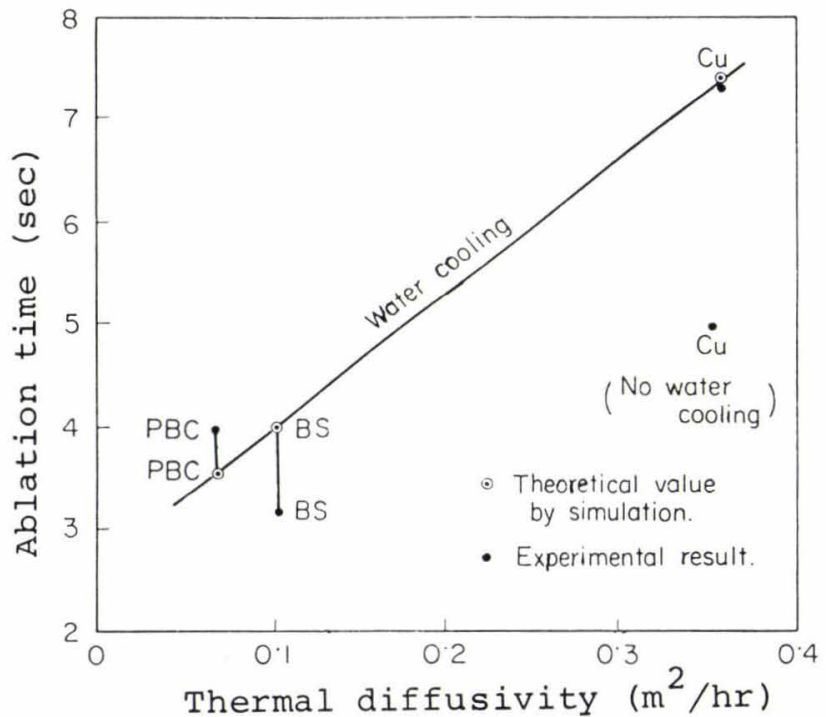

Fig. 2. The effect of thermal diffusivity on the ablation time of tuyere model

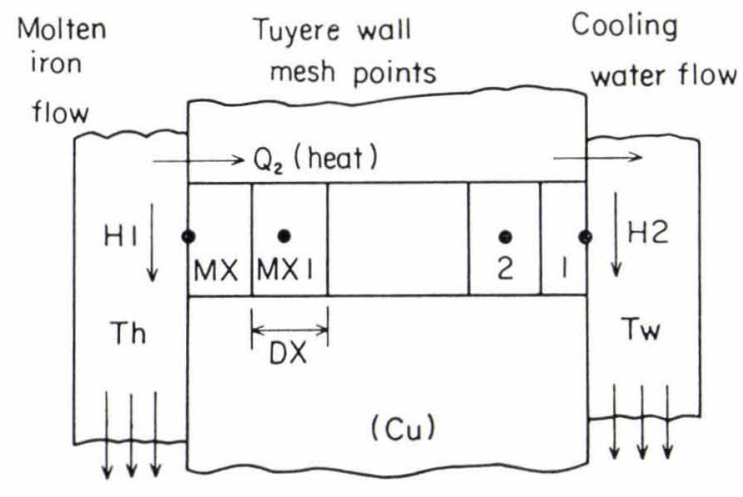

HI, H2 : Heat transfer coefficient

Fig. 3. Heat transfer simulation model at the heating up time before ablation starts

$$
Q_{1}=\frac{\lambda}{D X} \cdot\left[T(\mathrm{MX})-T\left(\mathrm{MX}_{1}\right)\right] \cdot D T \cdot S
$$

Next the quantity of heat transferred from molten iron to the point MX, $Q_{2}$, is expressed as follows.

$$
Q_{2}=H_{1} \cdot\left[T_{h}-T(\mathrm{MX})\right] \cdot D T \cdot S
$$

Substituting these equations into the equation for the heat balance

$$
Q_{0}=Q_{2}-Q_{1}
$$

it becomes as,

$$
\begin{aligned}
T D(\mathrm{MX})= & T(\mathrm{MX})+\frac{D T \cdot S}{C \cdot \rho \cdot V(\mathrm{MX})} \\
& \cdot\left[\frac{\lambda}{D X} \cdot\left\{T\left(\mathrm{MX}_{1}\right)-T(\mathrm{MX})\right\}\right. \\
& \left.+H_{1} \cdot\left\{\mathcal{T}_{h}-T(\mathrm{MX})\right\}\right]
\end{aligned}
$$

By the same procedure, when the temperature of the point I changes from $T(\mathrm{I})$ to $T D(\mathrm{I})$ for the period of $D T$, the equation for the heat balance at the inner point I can be expressed as follows.

$$
\begin{aligned}
\mathcal{T} D(\mathrm{I})= & \mathcal{T}(\mathrm{I})+\begin{array}{c}
D \mathcal{D} \cdot S \\
C \cdot \rho \cdot V(\mathrm{I})
\end{array} \cdot \stackrel{\lambda}{D X} \\
& \cdot[\mathcal{T}(\mathrm{I}+1)+\mathcal{T}(\mathrm{I}-1)-2 \cdot \mathcal{T}(\mathrm{I})]
\end{aligned}
$$

At the inner surface of the tuyere, the equation for the heat balance is given as follows.

$$
\begin{aligned}
T D(1)= & T(1)+\begin{array}{c}
D T \cdot S \\
C \cdot \rho \cdot V(1)
\end{array} \\
& \cdot\left[\frac{\lambda}{D X} \cdot\{T(2)-T(1)\}+H_{2} \cdot\left\{T_{w}-T(1)\right\}\right]
\end{aligned}
$$

2. Calculation of the Quantity of Heat Transferred before the Termination of Ablation

The quantity of heat necessary for melting a part of mesh point MX can be described by,

$$
L \cdot \rho \cdot V(\mathrm{MX})
$$

After the temperature of the mesh point MX reached the melting temperature, the quantities of heat transferred are calculated every $D T$ by subtracting the value of $Q_{2}-Q_{1}$ from the given value of $L \cdot \rho \cdot V(\mathrm{MX})$ until the value becomes zero. In these calculations, the temperature $T(\mathrm{MX})$ is kept constant. When the value of $\left[L \cdot \rho \cdot V(\mathrm{MX})-\left(Q_{2}-Q_{1}\right)\right]$ becomes zero, it is assumed that the ablation of the mesh point MX is finished. Thus the mesh point $\mathrm{MX}$ is ablated and washed away by the flow of molten iron, then the new surface mesh point $\mathrm{MX}_{1}$ is exposed to the flow of molten iron; in the calculation, $\mathrm{MX}$ is replaced by $\mathrm{MX}_{1}$.

3. Calculation of the Quantity of Heat Transferred during the Period of Ablation

It is not possible to estimate the thickness of molten 
copper layer on the surface of tuyere during the period of ablation. Therefore, the over-all heat transfer coefficient $\left(H_{3}\right)$ including the heat transfer effect of molten copper layer was used in this work. The arrangement of mesh point is shown in Fig. 4 where the thickness of molten copper layer is taken as $\delta$. The over-all heat transfer coefficient $H_{3}$ of the layer $\delta$ can be written by $(K / \delta)$ where $K$ is the thermal conductivity of molten copper. Since the value of $H_{3}$ can not be obtained easily by the method mentioned above, it is determined by the try and error method using a heat transfer simulation model.

The quantity of heat transferred into the mesh point MX for the period of DT can be expressed as follows.

$$
Q_{3}=H_{3} \cdot\left\{\mathcal{T}_{h}-T(\mathrm{MX})\right\} \cdot D T \cdot S
$$

The temperature rise at the mesh point on the surface of tuyere can be calculated by using the value of $Q_{3}$. In this calculation taken, the mesh distance $D X$ and the time interval DT are as follows.

$$
\begin{aligned}
& D X=1 \mathrm{~mm} \\
& D T=1 \times 10^{-5} \mathrm{hr}
\end{aligned}
$$

\section{Results of the Model Experiment and Its Heat Transfer Simulation}

The conditions adopted for the model experiment of the ablation of tuyere are as follows.

Wall thickness: $15 \mathrm{~mm}$

Temperature of cooling water: $25^{\circ} \mathrm{C}$

Flow rate of cooling water: $13.6 \mathrm{l} / \mathrm{min}$.

Initial temperature of the model tuyere: $20^{\circ} \mathrm{C}$

Temperature of molten iron: $1350^{\circ} \mathrm{C}$

Melting temperature of copper: $1083^{\circ} \mathrm{C}$

Latent heat of copper: $49 \mathrm{kcal} / \mathrm{kg}$

Density of copper: $8960 \mathrm{~kg} / \mathrm{m}^{3}$

Thermal conductivity of copper:

$340 \mathrm{kcal} / \mathrm{mhr}^{\circ} \mathrm{C} \quad\left(\right.$ at $\left.0^{\circ} \mathrm{C}\right)$

$290 \mathrm{kcal} / \mathrm{mhr}^{\circ} \mathrm{C} \quad\left(\right.$ at $\left.1000^{\circ} \mathrm{C}\right)$

Specific heat of copper: $0.1 \mathrm{kcal} / \mathrm{kg}^{\circ} \mathrm{C}$

\section{Determination of the Heat Transfer Coefficient and the} Over-all Heat Transfer Coefficient

By the try and error method based on the heat transfer simulation model, a reasonable heat transfer coefficient and an over-all heat transfer coefficient could be obtained, which were agreeable to the experimental results of the model tuyere ablation tests. Table 5 shows the heat transfer coefficient and the overall heat transfer coefficient calculated by the heat transfer simulation model. Since the values obtained for the simulation number 221 are very close to the experimental results, the following values were used for the calculation:

$$
\begin{aligned}
& H_{1}=13000 \mathrm{kcal} / \mathrm{m}^{2} \mathrm{hr}^{\circ} \mathrm{C} \\
& H_{2}=2000 \mathrm{kcal} / \mathrm{m}^{2} \mathrm{hr}^{\circ} \mathrm{C} \\
& H_{3}=30000 \mathrm{kcal} / \mathrm{m}^{2} \mathrm{hr}^{\circ} \mathrm{C}
\end{aligned}
$$

An example of the simulation results of ablation is shown in Fig. 5. It is seen from this figure that the temperature at the inner surface of the tuyere reaches $850^{\circ} \mathrm{C}$ at the time when the ablation starts on the

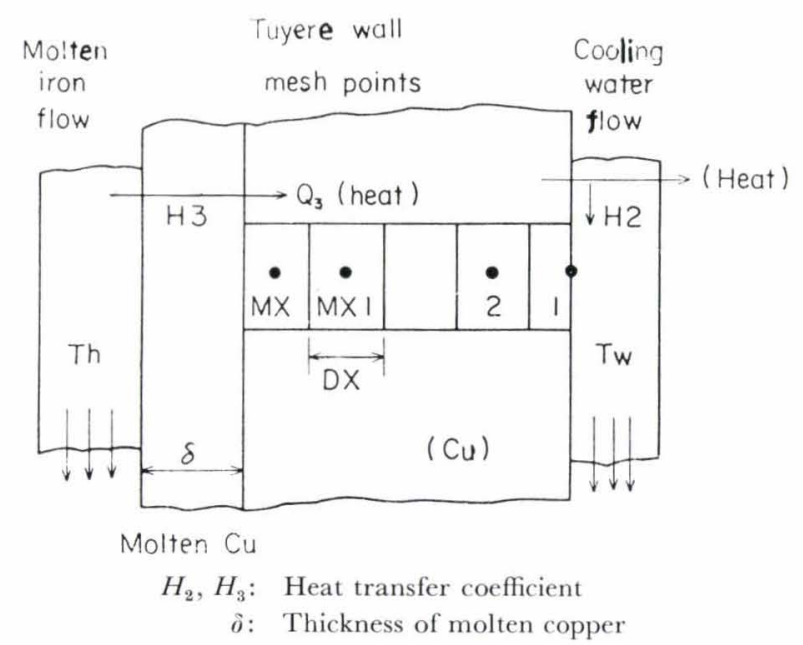

Fig. 4. Heat transfer simulation model in the period of ablation proceeds

tuyere surface, so the film boiling starts at the inner surface of the tuyere. The ablation would finish in $0.7 \mathrm{sec}$ after the temperature of the outer surface of tuyere becomes $1083^{\circ} \mathrm{C}$ (melting temperature of copper).

The time for the initiation of ablation was determined by observing the change in the flow direction of poured molten iron due to the ablated concave hole on the surface of model tuyere. The completion of ablation was determined by observing the outflow of cooling water from the model tuyere.

\section{Application of the Heat Transfer Simulation Model to the Cooling Effect on the Ablation}

As the heat transfer coefficient and the over-all heat transfer coefficient were obtained from the results of the model experiments and the heat transfer simulation model, the effect of intensive cooling on the ablation resistance will be discussed in this section.

\section{Influence of the Heat Transfer Coefficient and the Over-all Heat Transfer Coefficient on the Ablation Time}

Figure 6 shows an example of the results of the ablation time with various $H_{1}, H_{2}$ and $H_{3}$. The ablation velocity depends mainly on $H_{3}$. Figure 7 shows the influence of the thermal conductivity of the tuyere material on the ablation time.

\section{Influence of the Cooling Effect on the Ablation Time}

An example of the results of the influence of $\mathrm{H}_{2}$ on the ablation time is shown in Fig. 8. In order to prolong the ablation time, the value of $\mathrm{H}_{2}$ should be more than $9000 \mathrm{kcal} / \mathrm{m}^{2} \mathrm{hr}^{\circ} \mathrm{C}$.

In Fig. 9 the burn-out heat transfer coefficient is plotted as a function of the water velocity for several water temperatures. ${ }^{1)}$ It is seen from this figure that the temperature at the inner surface is $200^{\circ} \mathrm{C}$ when the temperature of cooling water is $56^{\circ} \mathrm{C}$ and the velocity is $12.8 \mathrm{~m} / \mathrm{sec}$. Under this condition, the ablation can be prevented. In other words, the velocity of cooling water should be over $12.8 \mathrm{~m} / \mathrm{sec}$ to prevent the ablation. 
Table 5. Tuyere ablation simulation results and experimental data of model tuyere

\begin{tabular}{|c|c|c|c|c|c|c|}
\hline \multirow{2}{*}{ Simulation number } & \multicolumn{3}{|c|}{ Heat transfer coefficient } & \multirow{2}{*}{$\begin{array}{c}\text { Ablation starts } \\
t_{0}(\mathrm{sec})\end{array}$} & \multirow{2}{*}{$\begin{array}{c}\text { Ablation finished } \\
t_{1} \text { (sec) }\end{array}$} & \multirow{2}{*}{$\begin{array}{l}t_{1}-t_{0} \\
(\mathrm{sec})\end{array}$} \\
\hline & $H_{1}$ & $H_{2}$ & $H_{3}$ & & & \\
\hline 111 & 11000 & 1000 & 50000 & 6.54 & 7.44 & 0.90 \\
\hline 112 & 11000 & 1000 & 70000 & 6.54 & 7.19 & 0.65 \\
\hline 113 & 11000 & 1000 & 90000 & 6.54 & 7.05 & 0.51 \\
\hline 124 & 11000 & 2000 & 150000 & 7.14 & 7.41 & 0.27 \\
\hline 211 & 13000 & 1000 & 30000 & 5.42 & 7.01 & 1.59 \\
\hline 221 & 13000 & 2000 & 30000 & 5.78 & 7.45 & 1.67 \\
\hline 232 & 13000 & 3000 & 50000 & 6.21 & 7.22 & 1.01 \\
\hline 243 & 13000 & 4000 & 70000 & 6.67 & 7.47 & 1.80 \\
\hline 244 & 13000 & 4000 & 90000 & 6.67 & 7.32 & 0.65 \\
\hline 245 & 13000 & 4000 & 110000 & 6.67 & 7.17 & 0.50 \\
\hline 311 & 15000 & 4000 & 30000 & 5.42 & 7.36 & 1.94 \\
\hline 322 & 15000 & 7000 & 150000 & 7.06 & 7.36 & 0.30 \\
\hline 323 & 15000 & 7000 & 200000 & 7.06 & 7.28 & 0.22 \\
\hline 411 & 17000 & 9000 & 70000 & 6.45 & 7.24 & 0.79 \\
\hline 412 & 17000 & 9000 & 90000 & 6.45 & 7.05 & 0.60 \\
\hline Model experiment & Cooling water & $13.6 \mathrm{l} / \mathrm{min}$ & & 6 & 7.5 & 1.5 \\
\hline
\end{tabular}

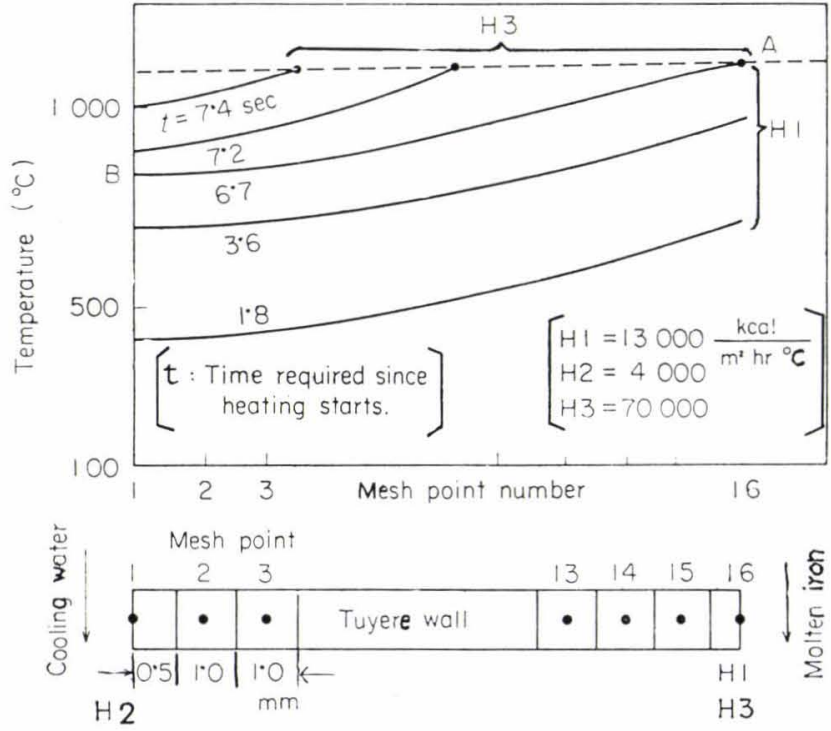

Fig. 5. Simulation result of tuyere ablation

Generally in the burn-out theory the maximum heat flux is used for burn-out. In the present work, the heat transfer coefficient was used in place of the burn-out heat flux estimated from McAdams' burnout diagram (Fig. 9). ${ }^{2)}$ The temperature and the velocity of cooling water and the inner surface temperature of the tuyere estimated from McAdams' burnout diagram are summarized in Table 6. It is seen from this table that the temperature at the inner surface is low when both temperature and the velocity of cooling water are low.

\section{Conclusion}

It became obvious from the examination of the broken tuyeres of our blast furnaces that the ablation failure mostly occurred at the upper and lower walls, and at the side wall.

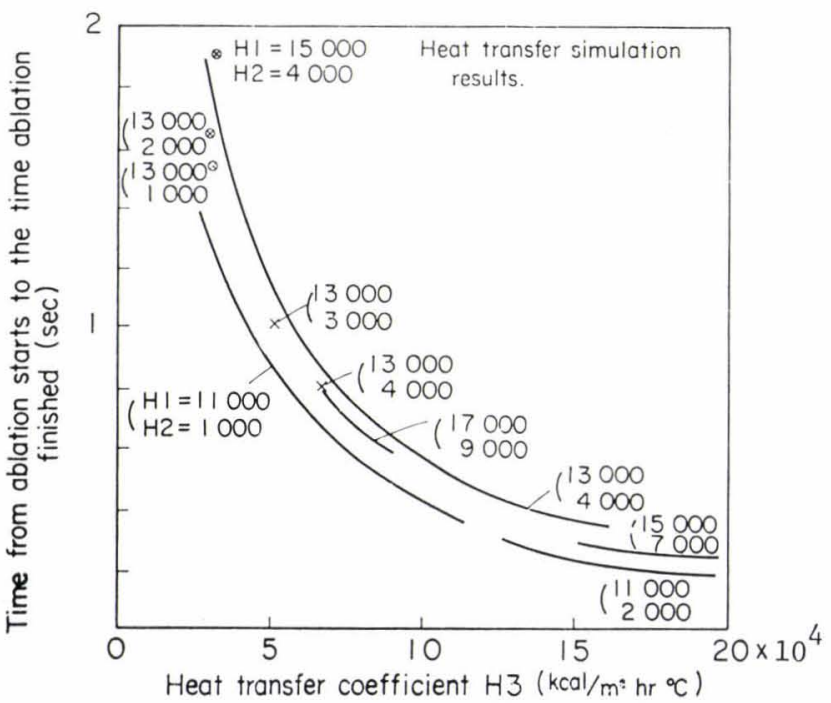

Fig. 6. The relation between ablation and heat transfer coefficients

In order to prevent the ablation of tuyere, some tests were made by using the model tuyeres. Based on the results obtained, the heat transfer model of ablation has been established and the heat transfer coefficients have been calculated by the heat transfer simulation of the model test. From this simulation, have also been examined, the influences of various factors on ablation.

The results obtained are summarized as follows.

(1) The ablation time is estimated as about $7 \mathrm{sec}$ from the experimental studies of the model tuyeres. The heat transfer coefficients are as follows.

$$
\begin{aligned}
& H_{1}=13000 \mathrm{kcal} / \mathrm{m}^{2} \mathrm{hr}^{\circ} \mathrm{C} \\
& H_{2}=2000 \mathrm{kcal} / \mathrm{m}^{2} \mathrm{hr}^{\circ} \mathrm{C} \\
& H_{3}=30000 \mathrm{kcal} / \mathrm{m}^{2} \mathrm{hr}^{\circ} \mathrm{C}
\end{aligned}
$$

(2) The velocity of cooling water should be over $13 \mathrm{~m} / \mathrm{sec}$ in order to prevent the ablation. 


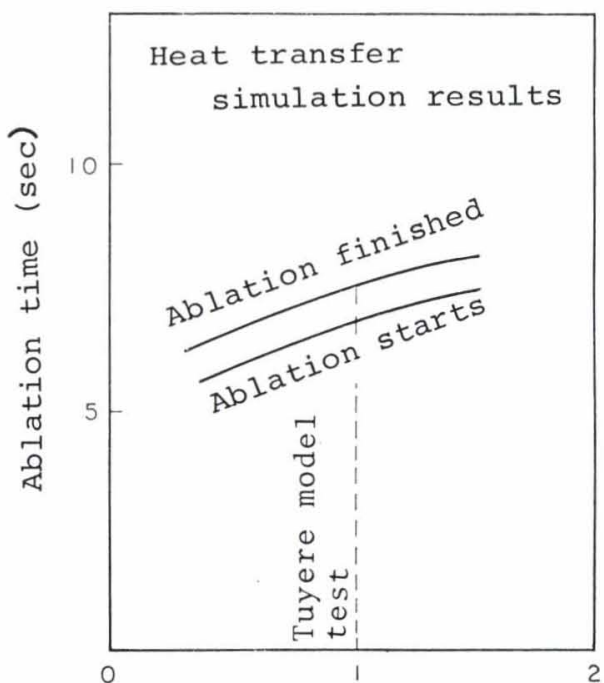

The ratio of thermal conductivity

$(\mathrm{K} / \mathrm{kCu})$

Fig. 7. The effect of thermal conductivity of tuyere

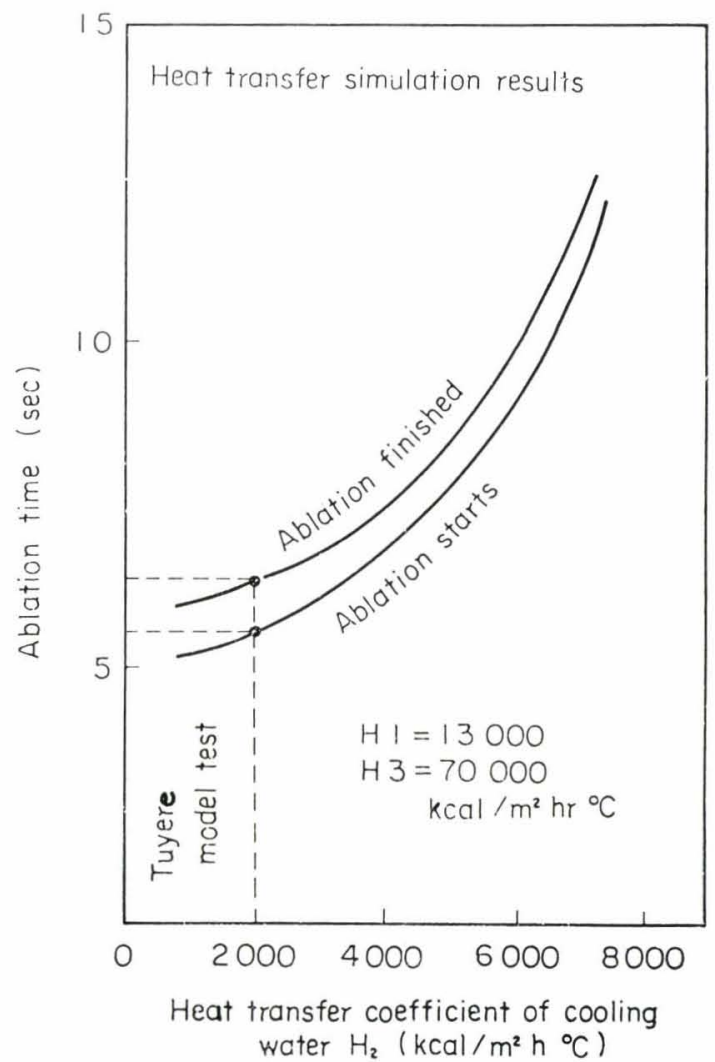

Fig. 8. The relation between ablation time and cooling water heat transfer coefficient $\mathrm{H}_{2}$ and the result of tuyere model ablation test

(3) It is not so effective to use copper alloy with slightly larger thermal conductivity than that of pure copper.

(4) It is desirable to thicken the tuyere wall for the prevention of ablation.

(5) It is desirable that the heat transfer coefficient is over $9000 \mathrm{kcal} / \mathrm{m}^{2} \mathrm{hr}^{\circ} \mathrm{C}$ to prevent the ablation.

Nomenclature

$C$ : Specific heat of copper $\left(\mathrm{kcal} / \mathrm{kg}^{\circ} \mathrm{C}\right)$

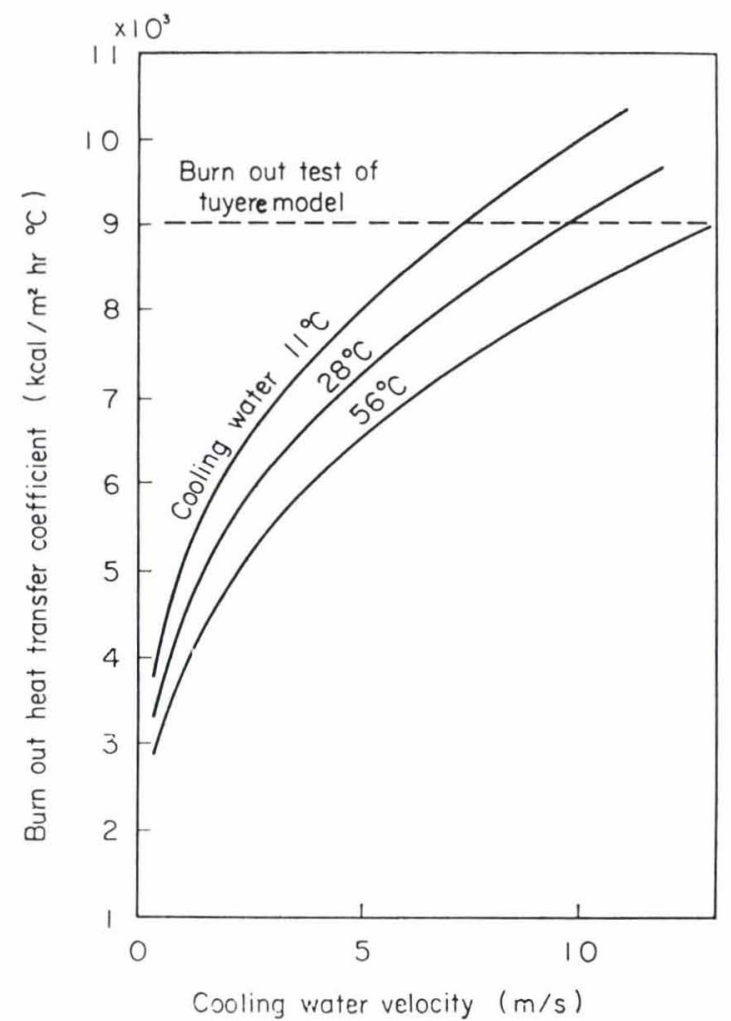

Fig. 9. Burn-out condition modified W. H. McAdams'data, and burn-out test result of tuyere model expressed by heat transfer coefficient

Table 6. Burn-out condition between cooling water temperature, cooling water velocity and tuyere inner surface temperature estimated by McAdams' burn-out diagram

\begin{tabular}{c|c|c}
$\begin{array}{c}\text { Cooling water } \\
\text { temperature }\left({ }^{\circ} \mathrm{C}\right)\end{array}$ & $\begin{array}{c}\text { Cooling water } \\
\text { velocity }(\mathrm{m} / \mathrm{sec})\end{array}$ & $\begin{array}{c}\text { Tuyere inner surface } \\
\text { temperature }\left({ }^{\circ} \mathrm{C}\right)\end{array}$ \\
\hline 56 & 12.8 & 200 \\
28 & 9.3 & 156 \\
11 & 7.2 & 144
\end{tabular}

$\rho:$ Density of copper $\left(\mathrm{kg} / \mathrm{m}^{3}\right)$

$V(\mathrm{I})$ : Volume at the mesh number I $\left(\mathrm{m}^{3}\right)$

$\lambda$ : Thermal conductivity of copper $\left(\mathrm{kcal} / \mathrm{mhr}^{\circ} \mathrm{C}\right)$

$D X$ : Distance of a mesh $(\mathrm{m})$

$H_{1}$ : Heat transfer coefficient between the molten iron and the surface of tuyere $\left(\mathrm{kcal} / \mathrm{m}^{2} \mathrm{hr}^{\circ} \mathrm{C}\right)$

$T_{h}$ : Temperature of the molten iron $\left({ }^{\circ} \mathrm{C}\right)$

$T_{w}$ : Temperature of the cooling water $\left({ }^{\circ} \mathrm{C}\right)$

$\mathrm{H}_{2}$ : Heat transfer coefficient between the cooling water and the inner surface of tuyere (kcal/ $\mathrm{m}^{2} \mathrm{hr}^{\circ} \mathrm{C}$ )

$L:$ Latent heat of copper $(\mathrm{kcal} / \mathrm{kg})$

$\mathrm{H}_{3}$ : Over-all coefficient $\left(\mathrm{kcal} / \mathrm{m}^{2} \mathrm{hr}^{\circ} \mathrm{C}\right)$

$S:$ Area $\left(\mathrm{m}^{2}\right)$

\section{REFERENCES}

1) M. Mitsutsuka, H. Morise and K. Tsuda: Tetsu-to-Hagané, 57 (1971), 2.

2) W. H. Mc.Adams: Heat Transmission, McGraw-Hill Book Co. Inc., Asian Student's Edition, (1954), 391, Figs. 14 21. 